\title{
Study on the Prevention and Countermeasure of Campus Network Loan Risk
}

\author{
Jing Zhang ${ }^{1}$, Wan $\mathrm{Ke}^{2}$, Yu Pan $^{3}$ \\ ${ }^{1,2}$ School of Economics and Management, Southwest Jiaotong University, Chengdu, 610031, China \\ ${ }^{3}$ External Exchange and Cooperation Division, Southwest Jiaotong University, Chengdu, 610031, China
}

Keywords: Campus network loan, Real harm, Illegal rsks, Risk prevention.

\begin{abstract}
In recent years, the development of campus network loan has developed rapidly and gradually formed a popular trend. This form of popular cannot be separated from the development of the network and individual needs. But what cannot be ignored is that the campus network loan has brought a huge burden to the students' psychological and family economy. The recent emergence of universities naked lenders new crime is that the community has caused a very bad impact. This paper will analyze the problem of campus loan which exists in 78 colleges in Sichuan Province, and select the university which is more prominent in the phenomenon of net loan. The paper summarizes the real hazards and illegal risks of campus network loan as well as propose the relevant recommendations in fighting against credit risk .
\end{abstract}

\section{The background}

Campus network loans, that is, the network loan company launched a new type of loan model for the college students, characterized by low threshold, small amount, fast lending, the typical P2P financial management model. Internet micro-credit has been very popular among college students. In this context, more and more students use online loans to meet the daily consumption needs, such as the purchase of electronic products, entertainment, travel, examination fees and so on. The statistics shows that college students network loan platform has reached more than 100 and many well-known brands are also committed to this area, but at the same time, some problems also surface: the overdue rate is 60 times the lowest, the unclear over six percent of the platform rate and so on. In Sichuan Province, for example, there are such loan platforms as credit", elite credit, campus e loan, tree age in the current market. College students' comparison mentality and irrational consumption concept aggravate the savage growth of many network loan platforms. Besides, given that there are a large number of colleges and universities in Sichuan Province, its population base being big, the campus internet loan needs to be highly vigilant and concerned about.

\section{The analysis of the status of campus network loan}

\section{The status of the campus network loan}

The campus network loan refers to the internet financial loan service for the university campus with student borrower as the consumer group. Compared with the traditional bank loan model, the campus network loan is fast, very attractive, and therefore widely welcomed by college students. With the help of attractive ads of 0 interest rate, 0 guarantees, no service fee, network plus agent model, network loans are rapidly spread in the college student groups. [2] Credit Management Research Center of China People's University released the National College Students credit awareness survey report in August 2015.

It shows that $8.77 \%$ of college students use loans to obtain funds, including micro-credit loans 5.33\% and network loans 3.44\%. 


\section{Statistical analysis of the status of campus network loans}

This paper chooses five colleges in Sichuan Province to carry on the detailed analysis and finds that the average number of students involved in the campus network loan of the five colleges is 68 and the number of the net loan platforms involved is as many as 87, its total amount of the loan up to 3.5 million. Most of the students involved in the school loan fund have per capita borrowing or consumption of less than 10,000 yuan, 700,000 yuan at most and 1,000 yuan at least. School students mainly use the campus network loan funds to buy electronic products, luxury goods, off-campus training and personal entrepreneurship.

The results of the survey show that some students overestimate their own repayment ability. Because the students spend more than their own economic capacity could afford, coupled with their own lack of stable income sources, it easily leads to the lack of repayment capacity. Second, the use of loans tends to diversify, of which the purchase of electronic products and daily consumption are the dominant. Several students use one loan to repay another.

\section{Investigation and analysis on the network loan of five universities}

Through the questionnaire survey and field interview form, this paper carries on the sample survey to the students of each grade and professional in five colleges in Sichuan province. The survey found that $80 \%$ of college students' monthly living expenses concentrate between 1000-1500 yuan, the living expenses mainly from parents and only $4 \%$ of students obtain a certain cost of living through scholarships, student loans and work-study program and the vast majority of students themselves have no source of income. The results show that the overall cost of living in college students is low, the actual purchasing power is limited and the potential of the development of campus network loan is bigger. After the relevant cross-analysis on data, it's found that boys have a higher consumption in the field of electronic products while girls in luxury goods such as cosmetics and brand-name package, such as the main consumer.

In this context, the campus network loan gets known to most students and some students use the campus network loan. The survey found that up to $70 \%$ of students understand the campus network loan, and some students use the campus network loan to varying degrees.

\section{The characteristics of campus network loan}

\section{Large consumer groups}

On the one hand, because college students have the higher ability to accept new things and they are prone to compare with each other, there is a general consumption impulse exceeding its own consumption ability in the college students. That's why they are easy to become the focus of marketing for all kinds of network loan platforms when they ignore the risks under the impulse of consumption. On the other hand, the marginal situation of bank credit card in the consumer market of college students leaves ample development opportunity for these stage shopping platforms. Internet financial enterprises have taken a fancy to the campus market thanks to the increasing consumption of college students who, as the dominant consumer of future financial services, are more easily accept the concept of Internet finance and thus bring them real business.

\section{A wide range of platforms and the high-speed growth of net loan turnover}

Last year, the national P2P network loan turnover exceeded 2.8 trillion yuan, reaching 2804.938 billion yuan, up 137.59\% over the previous year, 269\% in 2014, 259\% in 2015 and an average of $281 \%$ over the years. Net loan turnover still grows rapidly even if growth rate stays. Up to the end of 2016, net loan platform history cumulative turnover has reached 4.44 trillion yuan and national P2P network loan balance 121 million, a record high. In answer to the large campus network loan consumer groups, more and more platforms have been built targeted for college students. According to incomplete statistics, the number of such platforms in our country has reached more than 100 . These staging shopping platforms for college students are growing rapidly. 


\section{Low threshold of network loans}

The threshold for online lending is rather low, compared with the strict vetting and longer-time lending of banks. The lender may not have a guarantor, or only require his/her guarantor to provide a corresponding contact, without the written permission of the guarantor. The network loan also does not control the loan use and lacks the corresponding loan tracking measure. Even College students don't even have to sign up, they can easily complete a loan without meeting. On the e-credit platform, the loan items available include college students emergency loans and and free loans. Its publicity page shows: low threshold, no collateral and guarantee, just ID card and student card, full online operation, and elite school students can increase the amount of credit.

\section{The actual harm of the campus net loan}

\section{Inducing students to consume excessively and breed unhealthy habits}

College students are inexperienced and easily deceived. On the one hand, college students will take the risk of cheating because they choose the illegal, informal and dishonest network loan platform to blindly loan without fully understanding the real loan information. Some platforms like to play digital games on loan rates, that is, to promote low interest rates on the surface and the interest-free loans, but in fact, it is disguised usury; On the other hand, some college students have been lured into borrowing by campus agents or even companions because of their part-time needs.

\section{Lack of necessary risk cues}

Campus network loan platform mostly advertises itself 1-minute application, 10-minute audit, fast to 1 day lending, 0 mortgage, 0 Guarantee, low threshold and too simple procedure to require the lender himself to handle. Once such loans are built up, it may pose a risk to the net lending platform. Some campus loan platform information is not fully disclosed. It is not clear what the consequences will be for the students when they apply for staging, or how to pay for them, so that some of the immature college students do not know how much to put off the repayment, which may result in the student borrowing as rolling up.

\section{Hidden dangers to school safety and stability}

Most of the loan companies often take such measures as recourse, bullying, door-to-door charge, stalking and even illegally press for payments of debts. College students submit to humiliation considering academic study so they become the victim of usury over time and pay a painful price for it. Failure to return loan lenders in a timely manner would make the lenders to press for payments of debts for students via various means. Some lenders will ask for collateral of a certain value when they lend as well as student certificates, photocopies of identity cards in order to get a good understanding of students' personal information. Once students are unable to repay their loans on time, lenders may resort to intimidation, beatings, threatening students and even their parents to carry out the debt collection, which poses a major hazard to students personal safety and the university's campus order.

\section{Lack of necessary supervision}

Campus network loans belong to the Internet finance, and the current China adopts the financial sector supervision. Campus Loan belongs to the internet financial category, but the state has no corresponding laws and regulations for it, nor clear supervision departments, so the supervision of such companies and platforms is still none. At the same time, the company's industrial and commercial registration information show that the existing campus loans registered companies are economic information consulting or investment management services companies which only need to provide relevant information when registration that is very easy. They are different from micro-finance companies whose registered capital must be in place. Therefore, it's difficult to supervise such a platform even if when the illegal circumstances appear in it, for example, some campus loans companies handle the same business as financial units and micro-finance companies. 


\section{Suggestions on preventing the risk of campus network loan}

\section{To strengthen student education management}

First, to guide the rational consumption of college students, to master some necessary financial knowledge, to cultivate their own credit awareness and contract spirit; They are required to learn to control money, establish a sense of risk, put advance consumption, credit investment and other controls within a reasonable range and spend the money and time on the things with long-term interests. Second, strengthen the college students' wealth-generating business education. Colleges should set up some financial management knowledge courses to strengthen the education of college students' financial basic knowledge, raise students' sense of risk, and prevent the traps of excessive consumption. Third, strengthen the education and cultivation of college students' world outlook and outlook on life and values. Colleges should take responsibility for it seriously and change the traditional stocking-type management. So they not only need to respect college students rights to be independent, but also cultivate healthy and qualified talents with all-round development. They need to pay attention to all-round guidance and growth intervention, rather than let college students grow up freely.

\section{Do a good job of risk tips}

First, to carry out a variety of campus network loan risk tips and publicity and education activities with the local education departments, universities and financial institutions. During the the student's opening period, the banking institutions should be guided to the park to carry out the financial knowledge propaganda of preventing illegal fund raising, investment financing, student student loan, mobile banking and electronic bank in order to strengthen the students' consciousness of network financial security and self-protection, and establish the correct consumption view. The second is to standardize the network lending platform exhibition industry behavior and pose demands for the network loan platform in the investigation process by the appointment of legal person, and talk with senior executives in order to prohibit the network loan platform into the campus, prevent the employment of students engaged in agency campus loans to profit and the use of illegal means to press for debts. Third, establish the monitoring mechanisms and joint with the relevant departments to take the initiative, closely track and timely feedback local campus credit public opinion to prevent and combat the use of the campus network loans about to eliminate the campus credit environment.

\section{Establish the working mechanisms, and strengthen risk prevention}

One is to establish information sharing mechanism. Strengthen the organization and coordination of interdepartmental, inter-regional to exchange information and achieve timely control, early detection, early warning and early disposal. The second is to establish linkage mechanism. Supervision departments, education departments and colleges and universities carry out a comprehensive verification of the campus network loan platform to establish the work linkage day-to-day mechanism, clear division of labor, implement responsibility and find signs to make a proactive attack. In particular, if the individual campus network loan platforms are found to be suspected of setting up funds pool, offline marketing, exaggerated or misleading publicity and other irregularities. Based on the degree of risk, the nature of illegal violations, the seriousness of the plot, the extent of social harm, treatment methods, they will be classified and differentiated measures will be designed timely to prevent the disposal of risk. To ensure comprehensive risk-checking, comprehensive treatment and supervision of comprehensive coverage in order to create a good campus environment. Third, to launch a special attack. The relevant departments such as CBRC, industry and commerce, work letter, finance Bureau and Public Security should jointly carry out violation of the P2P platform and illegal action to establish a long-term mechanism to crack down on suspected violence bizhai, suspected illegal operation and other violations, illegal activities and timely punish financial institutions for their use of violence to earnestly maintain the Internet financial order and campus security and stability. 


\section{Improve the regulatory system and norms}

First, the functional departments should introduce pre-emptive norms, clear the relevant departments of the regulatory responsibility, improve and refine the relevant laws and regulations, support the establishment of rapid complaints channels, improve the "campus loan P2P platform enterprise risk assessment, information disclosure and other mechanisms and effective supervise platform for the operation of business and wind control measures in order to promote the campus loan P2P platform for its healthy and orderly development. Second, the financial regulatory authorities should strengthen the campus loan business supervision, require business departments to standardize the audit process, strictly review the identity of the lender, qualifications and repayment capacity and those who audit the information carelessly should be held accountable. Finally, given the fact that the current imperfect domestic personal credit system and the lack of large accumulation of platform data restrict the network loan industry to avoid the risk of the status, it's proposed that a unified campus financial center be set up in the school to improve the campus financial credit system. Students Information, loan records, repayment capacity will be assessed by the third-party, and all the loans issued by platform loans including campus loan will be audited through the financial center, thus putting an end to such problems as "one more loans" and unable to repay arise for students online Borrow "plus a safety valve". At the same time, the college students net loan platform data will be added to the credit system as soon as possible to break the status quo of the closed information between the platforms and improve the level of industry risk control.

\section{References}

[1] Bao Yanlong. Investigation and Analysis on the Development of Campus Network Loan, Credit, 2016,(08):73-75.

[2] Guo Yingying. Research on the Current Situation and Standard Method of Campus Network Loan, Smart City,2016,(11):141.

[3] Huang Lei. Strict admittance mechanism to standardize campus network loan, Prosecutor's Daily. 